\title{
Visualisation of Written Culture with Digital Collage and Woman Representation: Visualisation of Woman Figure in the Mountain and Sea Themed Turkish Cypriot Legends
}

\section{Gurkan Gokasan}

\author{
Instructor at Faculty of Fine Arts and Design, \\ (PhD progress) Near East University (North Cyprus) \\ Assoc. Prof. Dr. Erdal Aygenc \\ Vice Dean at Faculty of Fine Arts and Design, \\ Near East University (North Cyprus)
}

Doi:10.5901/mjss.2017.v8n3p45

\begin{abstract}
This study aimed to visualise the written versions of legends, which can transform the intangible culture as one of the significant parts of culture covering human facts and some habits like art, customs, traditions, into the tangible culture which is the other part of culture, through certain theme/s. Within this perspective, the study aimed to transform the women and discursive representation styles given in the Turkish Cypriot legends into visual representation in addition to creating an absolute language through the use of homogenous indicators. The study discussed the woman described with the 'passive', 'oppressed', 'victim' and 'sinful' features, in brief her marginalisation with the patriarchal legend structure through the use of semiotics. For the visualisation of legends, regardless the positive or negative consequence of woman, the 'torn paper collage with its popular name - texture was used to create a common language and the emotions to be reflected were symbolised with various colours. The content references of colours were taken into account; for instance, purple was used in the images that woman was downtrodden and blue in the images with the dominant male hegemony. Since the themes covered generally referred to the 'mother nature', the woman figures were illustrated as naked delivering the woman in her purest, simplest and most natural self without the social status indicators symbolised by the clothes. The main scene and woman figures, mountain and sea motifs in the selected legends were re-fictionalised in the digital environment and finalised with the illustration. As the effectiveness of pictorial elements in teaching and facilitating to remember the legends, as a cultural element within the main scope of this study is known, the legends were illustrated through the digital collage method. Therefore, the contribution was aimed to be reflected on the permanence and popularity of legends as a cultural product and verbal asset with the benefits of visual and artistic language.
\end{abstract}

Keywords: Digital Collage, Turkish Cypriot Legends, Woman Figure, Written Culture, Mountain and Sea Theme

\section{Introduction}

According to Ergün (2012), the digital collage developed as a different expression style varying from the traditional collage understanding had become alive outside the canvas with the development in technology, the creation of 'expressions' stuck on the canvas in digital environment had opened new paths for expression alternatives in modern art. The decision on how to create the artistic expression through the use of what means within the framework of originality and creativity depends on the implementation of modern and brave decisions with a colourful range (Ergün, 2012). On the other hand, Berger (2004) indicated that the collage technique gives various opportunities for the artists who want to accomplish in the creation of new work. Hence, a various collage materials such as newspaper pieces, sand, metal, cigarette package provides the artist different expression styles when rather than the traditional styles. Therefore, the indefiniteness added into the material search of artist comes out as the manifestation of free-thinking skill, and the status of collage technique, which challenges the middle-class sense of art as "invaluable", has become different (Berger, 2004). 
The creativity concept originated from the mind is a concept that can develop, change and renew. The equipment used at the practice phase might be a simple pen as well as a state-of-art computer program. The determinant in the nature of outcome is the style of reflecting all knowledge and experience to a paper, canvas or screen in a certain system rather than the tools. In the visual creativity, there are two main production method and technique as analogue and digital (numeric), both of which have their own advantages and disadvantages. When chosen as a design space, the digital environment provides the opportunities to renew, change and increase the options. The important aspect is the artistic design nature and sufficiency. Şengül (2006) argued that the digital environment is an opportunity, which is cost effective and remediable with high compensation.

\section{Institutional Framework: Visual "Arouse" of Legends with Digital Collage:}

\subsection{Culture, Society and Art:}

Culture that can be defined as a system produced by the society and at the same time building the existing society, have vital responsibilities in the assessment of social structures. In other words, culture, as a wide and systematic information, comprise all human products that continue as an applicable tradition in a society covering all life elements including art as being non-static and developing and changing continuously.

The signs and symbols serving to distinguish societies are considered to cover and interpret the values of society, establish the social solidarity elements and ensure their development. Therefore; the culture might be universal, social, sustainable, learnt and taught, variable and symbolic. The societies expressing their own cultures by signs and symbols and their associated behaviours may predicate different meaning in other social groups. Pursuant to Özkalp (2005), the components of culture are tangible and intangible. Özkalp also noted that each concrete product of society during the development phase is referred by the tangible culture, while the intangible culture covers the values, beliefs, customs and traditions of a society (Özkalp, 2005).

Akdoğan (2001) defined the art as one of the main components of culture as "the whole methods, information and rules related with the performance of any activity or task" (p.213), and the artistic activity as a creative human activity towards the transmission, expression or convey emotions, idea and aims, status or events through skills and imagination by the use of experiences. Within this perspective, the artistic activity might be considered as a personal communication tool in itself and a cultural product at the social level. Ünver stated that the style and meaning of art are directly linked with the period, social structure and geography what it is produced while underlining the relation between the art and culture. Unver also indicated that the culture is the tangible, formed expressions of cultures owned by the societies and a social structure oriented language.

\subsection{Legends as a Cultural Product}

The legends as a part of culture are mainly discussed under the ethnology. Nesim and Öznur (2011) defined a unique cultural heritage of societies comprised of people living together for many years as a society or community and indicated the science working on the cultural heritage of such communities as 'ethnology'. Ethonology can also be defined as the science, which researches, discusses, categorises culture with its unique methods, steers the future and interprets accordingly. The researches and methods on the ethnology show the current improvement in this science with an enriched content. Although the ethnology studies in Cyprus are still new, a progress has been made and many works contributing on the tangible and intangible culture as "folk literature" were created.

Alptekin (2013) defined the legend as the folk narratives in the style of convincing, short and prose. According to the author, the origin of legends is the mythology and texts of tales, and they are considered as an independent style since $19^{\text {th }}$ century.

\subsection{Past, Present and Future of Collage Art}

As noted by Rona and Beykal (1997), the cubism, which has a significant place in the historical development of collage, had emerged in the early $20^{\text {th }}$ century under the pioneering of Pablo Picasso and George Braque as a result of anxiousness and dissatisfaction of the new generation artists with their difficulties in portraying the modern life and seeking a new way of expression, due to their non-identification with the art movements in the end of $19^{\text {th }}$ century and their art movements (Rona \& Beykal, 1997).

Since the beginning of collage art, the painting artists using various techniques and materials had introduced the 
diversification and development of new expression styles in parallel with the developing technology. In accordance with the opportunities from the industrialisation and technology, the artists began to bring different technique and materials in their paintings and they had integrated the collage technique into the painting art.

As discussed by Wölfflin and Örs (2000), the significant changes in the part and whole had started while going from $16^{\text {th }}$ century to the $17^{\text {th }}$ century as a switch from the closed form to the open. In the $16^{\text {th }}$ century, the painting was based on the size of canvas while in $17^{\text {th }}$ century it went beyond the frame and arouse outside of the painting. Therefore, the audience complemented the duty of formation the remaining pieces in the mind and making it a whole (Wölfflin, 1985).

Pursuant to Lynton (2009), Gaullime Apollinaire explained the collage as a technique that can illustrate the life style of modern city people and he maintained as a defender of this art until he passed away. According to the author, the art movements pursuing 'a new expression' and 'new technique' had brought the unique pieces of collage and included 'the difference of texture' with the aim to create a new work. Within this perspective, Apollinaire in consideration with this logic behind the collage reflected the speeches that he heard in pieces yet in his own style (Lynton, 2009).

In addition to the traditional art materials, with the aim of finding different materials and techniques, sand also introduced together with the newspaper, magazines, posters, label, string and fabric that were all used for the first time. Therefore, it is possible to interpret that Picasso and Braque integrated the object that they would paint directly into the painting. Hence, with the collage technique, the materials other than the paint had become a painting material.

\subsection{Changing status of collage with the developing technology and industrialisation: Digital Collage Art}

The digital collage technique originated as a product of developing technology and industrialisation bear the traces of traditional collage technique. The works that are created by combining more than one found object on the computer environment have provided an opportunity for the artists seeking an innovation through the transfer of canvas into the computer.

According to Greh (1990), the tools such as keyboard, mouse, pen light and tablets are utilized to create an image on a computer and make edits such as drawing, illustration and manipulation. Hence, the loss of time and financial resources is minimised and new and different results are obtained through merging the traditional tools with the technology.

As indicated by Sağlamtimur (2010), the factors such as the momentum in technology, less geographical boundaries, elimination of physical problems and decrease in the digital technologies, provide the change and improvements in the art and culture domains. According to the author, the means by the new digital technologies lead the creation of new formats and new expressions have emerged. Hence, the computers can be considered as representing a significant part of the digital technologies as well as contributing to the creation of art and artistic works (Sağlamtimur, 2010).

Unlike the traditional collage technique, today the colours and forms and reflected on the computers rather than the canvas and new images are created via the specific graphic programmes. Through the utilisation of technological opportunities, the artists have the chance to create faster and more options to choose form in the delivery of their creativity and artistic expression when compared with the traditional techniques. Therefore, the collage technique might be stated as transformed into digital in certain extent with the digital era, and such circumstance has enriched the imagination.

The developing and changing technology has built bridges between art and itself and provided new opportunities for the artist to create works in the domains of painting, photography, drawing and sculpture. Although the works reflect the characteristics features and style of digital platform, sometimes it is not possible to understand that such works are the products of a digital process. The manipulation is possible by digital technologies, which lead the photography works; new collages with new tastes can be created as a result of combinations between painting, sculpture, graphic and photography. In the early $20^{\text {th }}$ century, the techniques, which were used by the Cubist, Dadaist and Surrealist artists and suitable for appropriation their works via using collage, editing and montage, have become easier with the development in the digital technologies (Sağlamtimur, 2010).

\subsection{Turkish Cypriot Culture and Written Turkish Cypriot Legends}

Alptekin (2013) expressed that similar to the Turkish literature, there are two types of legends in the Turkish Cypriot literature; the first as the written styles of menakıbnâme and velayetnâme; and the second as being different than the first in the verbal format. According to the author, although there were no examples found in Cyprus for the first type, many researchers identified the verbal resources (Alptekin, 2013).

Serdar (1966) defined legend as the stories told of the events visualised in the minds of society or people telling the legend by shaping extraordinary features. The feature distinguishing the legends from the epics is that they are 
delivered in a non-artistic and unembellished way of expression (Serdar, 1966).

As mentioned by Nesim and Öznur (2011), Cyprus had become a home to many civilisations due to its strategic location. Therefore, the cultures of such civilisations might be found in the Cyprus Turkish culture. Gökçeoğlu (2004) expressed that the legends have mythological, historical, religious and imaginary/fantastic roots. Particularly the mythological traces of Egyptian, Phoenician, Jewish, Anatolian and Ancient Greek civilisations can be easily observed on the Turkish Cypriot legends (Nesim ve Öznur, 2011).

Gökçeoğlu (2004) noted that the Sakaoğlu classified the legends in total eight main groups on the basis of their features: Love, Escaping from the Bad, Disrespectfulness, Bad Habits, Godsend and People, Various Petrification, Incomplete Narration and Change of Shape. Gökçeoğlu (2004) stated that the Turkish Cypriot legends are mainly included change of shape motifs the most and listed the sub-sections of this motif as: Turning into Stone, Turning into Animal, Turning into Plant, Turning into Mountain/Hill, Turning into Sea/River/Lake/Spring, Turning into Space Objects, Turning into Supernatural Objects, Turning into Natural Events, Turning into Mine, Turning into Human and Incomplete Narrations.

\section{Method}

\subsection{Data collection and Analysis}

The book by Mustafa Gökçeoğlu (2004) 'Turkish Cypriot Ethnology Oral Culture Assets: Legends' was used as a basis for the study and an in-depth analysis and research were conducted to clarify whether there are variations of legends covered under the aim of this study.

The relevant book has a total number of 94 Turkish Cypriot Legends classified under 24 categories. Classified in accordance with the similarities in their themes, 8 out of 12 legends categorised as the legends about the Mountain/Well/Plain, and legends about the Sea/Lake/Shore under a total number of 94 legends were take as main data. As a result of this classification, the figure/representation of "Woman" in the legends with 'mother nature' elements was taken as the main figure.

"Beşparmak Dağı/Beşparmak Mountain", "Aslan Ali/Brave Ali", "Ihanetin Bedeli/Price of Affair", "Gavur Kayaların Gözyaşı/Tears of Giaour Rocks" from the legends about Mountain, Well and Plain in addition to "Püsküllü", "Tuz Gölüne Dair Efsane/Legend of Salt Lake", Yılan Adası/Snake Island", "Sarnıç Kızlarının Ölümü/Death of Cistern Girls" from the legends about Sea, Lake and Shore were selected for visualisation by the digital collage method.

\subsection{Case study}

Since the book by Mustafa Gökçeoğlu (2004) 'Turkish Cypriot Ethnology Oral Culture Assets: Legends' is the one of the most up-to-date and comprehensive source in the literature that narrates the Turkish Cypriot Legends systematically into writing, it constituted the basis of the study in terms of "case study".

\subsection{Limitations}

Within the scope of Turkish Cypriot Culture and Literature, only Turkish Cypriot Legends were taken as a basis in this study. Moreover, the legends were also confined to a scene from 8 legends including "Woman" figure/representation under the legends about the Mountain/Well/Plain, and legends about the Sea/Lake/Shore, which were visualised by digital collage technique.

\section{Findings and Assessment: Turkish Cypriot Legends about "Mountain, Well and Plain" and "Sea, Lake and Shore" and woman representation}

\subsection{Legends About Mountain, Well and Plain}

\subsection{1 "Beşparmak Dağı/Beşparmak Mountain" Legend and woman}

In the legend of Beşparmak Dağı, two young men duelled for the woman they love. When one subtly pulled his rival into the marsh that he fell, both died (Gökçeoğlu, 2004).

The legend put woman forward with her "beauty" and did not mention any emotional bond to any of the men duelled 
for her. Hence, it is possible to say that the woman was "passivized". While the legend did not indicate whether both men described as "bad man" and "good man" respectively got any feeling back from the women they loved, the legend aimed to impose the idea that the woman had no say in this relationship and the strong one could "own" the woman he loved.

\subsection{2 "Aslan Ali/Brave Ali” Legend and woman}

The main theme of the legend, which is about a forest surrounding the Beşparmak Mountains, is that people have the potential to betray primarily to the nature and even to their closest relatives for their own benefits. The legend is about the son of a man, killed by the King in order to protect the forest, and his struggle for the protection of same forest and him being betrayed for 'love' after he trusted to the prince (Gökçeoğlu, 2004).

In the related legend, it is narrated that the Prince was in love with the daughter of the neighbouring King and King might allow him to get marry with his daughter with the condition of big forest; and the Princess with no say at all was "commoditised" by forcing into marriage in exchange of good.

\subsection{3 "ihanetin Bedeli/Price of Affair" Legend and woman}

This legend narrated two fishermen and the love of fisherman from Dipkarpaz to the wife of fisherman from Sipahi, and their affair (Gökçeoğlu, 2004).

The woman defined as "a traitor" in the legend died with her lover as a result of stroke of lightening when they were together. The legend illustrates a woman having an affair and there is an ending regarding the "divine justice" being the determinant.

\subsection{4 "Gavur Kayaların Gözyaşı/Tears of Giaour Rocks" Legend and woman}

The legend describes the Bellapais Temple where the Mediterranean pirates were taking shelter as well as priest and priestesses were living. A feast was organised once a year in this temple and young girls offered themselves to men with the wish to find a husband. However, one day God melted down and destroyed Gavur Kayaları (Giaour Stones) together with the people due to the sin of the archpriest (Gökçeoğlu, 2004).

In the legend, it is observed that the girls narrated as "pure and virgin" had no choice on men that they 'surrendered' or could not have any emotional bond. The young girls with prominent physical features are shown as 'innocent' as well as commoditised. The images for the girls created in the mind of the readers might be summarised as 'innocent', 'passive', 'attractive' and 'submissive'.

\subsection{Legends About Sea, Lake and Shore}

\subsection{1 "Püsküllü" Legend and woman}

The legend mentioned the fire in the sea on certain days to gather "beautiful" and "ugly" and a crazy youngster with the strength of "a giant" named Püsküllü burnt the girls that he killed for his love at the sea side.

Püsküllü, who threw his most loved blond girl into the sea, regretted that and secluded himself. The other girls dragged Püsküllü out of his cave, took to the seaside and lighted a fire. Upon the sad song of blond girl from the sea, he got into the sea and disappeared within the dust cloud vy the big waves (Gökçeoğlu, 2004).

The related legend described the woman that Püsküllü was in love with, risked her death for love and invited Püsküllü lighting a fire in regret despite of everything happened. The legend narrated the woman as 'a brave' and 'fearless' character turning up for her love and what she believed for.

\subsection{2 "Tuz Gölüne Dair Efsane/Legend of Salt Lake" and woman}

The legend is about a dervish, who felt thirsty when he visited a vineyard owned by an old woman at the place of Salt Lake in İskele, and asked for grapes. The old woman did not offered him any, he got angry and the vineyard became a salt late with the curse of dervish and the old lady turned into stone, the dervish died due to thirst and exhaustion while his claw wand had become a carob tree (Gökçeoğlu, 2004).

The legend narrated the old woman, who did not give any grapes to the dervish, as he was about to die due to thirst, as 'stingy and grumpy' while emphasized the negative results of lie and cupidity. 


\subsection{3 "Yılan Adası/Snake Island" Legend and woman}

This legend took place at the Snake Island known as the 'love island' that transformed into an island with the merge of snakes with the land. The aggressive king sent his men to arrest the fisherman and his daughter. Resisting in surrendering, the fisherman sailed. The kind did not find the fisherman, wife and daughter, and contracted an irremediable disease. The king returned to the island and was stranded there; the island went down into the water. The legend narrated the king coming out of a snake (Gökçeoğlu, 2004).

The related legend narrated the wife of fisherman as a 'beautiful' woman and 'brave', 'fearless' and 'loyal' risking in protecting her husband and daughter from the fury.

\subsection{4 "Sarnıç Kızlarının Ölümü/Death of Cistern Girls" Legend and woman}

The legend was taken place in the Belen Plain around the Kyrenia Yüzbir Evler Castle and about the vows at the Belen Cistern and the holiness of this cistern. The Shepherd Vakua sacrificed the sins of his wife for the God and Angels. Since then, too many problems aroused and women started to sell their virginity for a piece of bread. Then the fruitfulness increased at the cistern and feasts were organised. The legend narrated two lovers getting into the sea and disappearing in the bubbles after a feast that they participated with their one-day leave from the imprisonment in the Yüzbir Evler Castle (Gökçeoğlu, 2004).

The legend mentioned the stories of women selling their virginities due to the drought in order not to die from hunger and how they are 'commoditised' and that they had to lose their virginities for survival.

\subsection{Visualisation and Assessment of 'woman' in the Legends about Mountain, Well and Plain}

\subsubsection{Visualisation and Assessment of 'woman' in the "Beşparmak Dağı/Beşparmak Mountain" Legend}

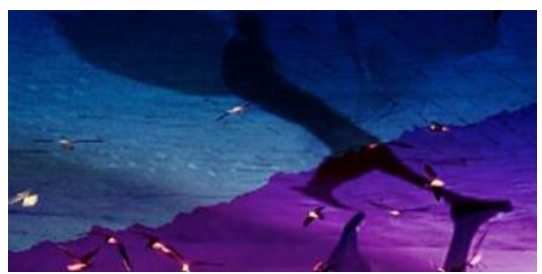

Figure 1. 'Woman' in the "Beşparmak Dağı/Beşparmak Mountain" Legend

The 'passivation' of woman in the Beşparmak Dağı mountain legend was tried to be described with 'torn' effect in the visualisation phase; the woman was represented with purple colour associated by the globally known woman rights movement (Abbandonato, 1991). Additionally, the fact that woman had no say about the men competing for the woman and accepted to be 'chosen' or her destiny, which was represented with a head bent woman. Tabooing and considering such selection-to be selected as normal were illustrated with 'brick wall'. The blue colour representing men were used from dark to light referring to a patriarchal order.

\subsubsection{Woman representation and assessment of woman in the "Aslan Ali/Brave Ali" legend}

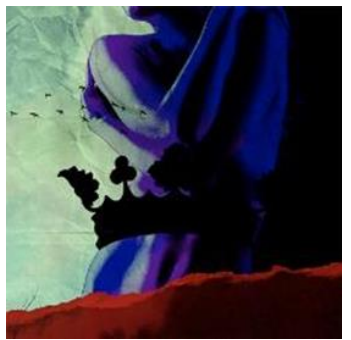

Figure 2. 'Woman' in the "Aslan Ali/Brave Ali" Legend 
The fact that the prince, who was in love with the neighbouring princess, had taken the risk to give his big forest to the King to be with the princess means the 'passivation' and 'commoditization' of woman. Such meanings were represented with a woman image in purple colour, crossed her arms giving the feeling as if she was cold/afraid. The crown on the waist of woman figure representing the princess shows her status and its being on the waist instead of her head indicates that she was in a dilemma. Offering her virginity against goods and her passivation were illustrated with red torn paper texture.

\subsection{3 "Ihanetin Bedeli/Price of Affair" Legend and woman}

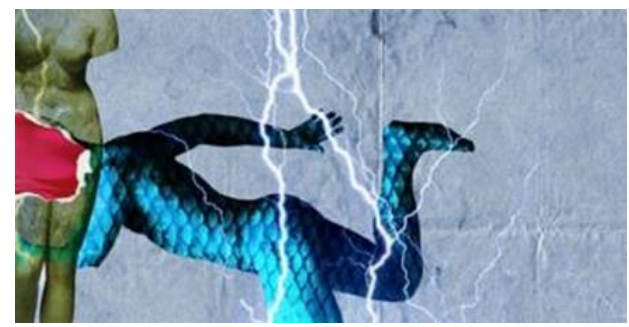

Figure 3. 'Woman' in the "Ihanetin Bedeli/Price of Affair" Legend

Since woman in the legend of "Ihanetin Bedeli/Price of Affair" was narrated with the negative features as "betrayer" and "traitor", the sexual area of the stoned woman body was visualised with bloody torn. Also, the dilemma of the stoned woman was expressed by a sculpture without any arms. Due to the occupation of fisherman and cold and slippery texture of fish, the fish scales were used on the background. The lightening images were used to illustrate their punishment with the God's fury due to their love affair; and the creased paper texture was for the exhaustion of the woman for the affair and the grey colour was used to symbolise the 'sadness' in the existing situation.

\subsection{4 "Gavur Kayaların Gözyaşı/ Tears of Giaour Rocks" Legend and woman}

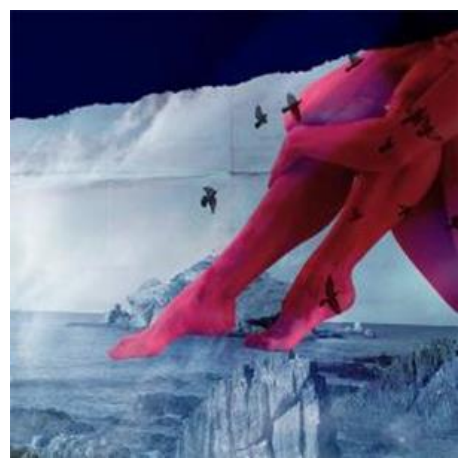

Figure 4. 'Woman' in the "Gavur Kayaların Gözyaşı / Tears of Giaour Rocks" Legend

The woman image given in the legend called Gavur Kayalarının Gözyaşları/tears of Giaour Rocks was narrated with red colour representing sexuality and virginity in the Eastern culture. The woman image figuring the wait of women to offer their virginities to the men hiding behind the rocks with an order of the Archpriest was supported with the dark blue colour torn paper texture. The flying of birds representing the freedom towards the woman figure represents the sexual liberation of women after having an intercourse with a man at the end of this feast. 


\subsection{Visualisation and Assessment of 'woman' in the Legends about Sea, Lake and Shore}

\subsubsection{Woman in "Püsküllü" Legend}

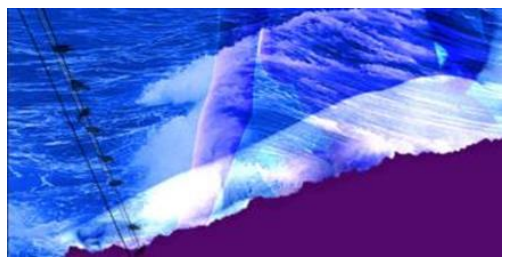

Figure 5. 'Woman' in the "Püsküllü” Legend

There are two women figures in the legend of "Püsküllü". The first woman visualised as the one coming to the fire of Püsküllü and being ready to surrender herself to the man she loved again represented with purple colour. Taking the right to live, one of the most fundamental rights away from the woman was represented with the purple colour as the colour of feminism. The second woman figure, which Püsküllü threw into the sea and gave up hope from was visualised as lost in the waves as trying to stand up. The second figure illustrated in a much transparent way represents the woman soul killed by Püsküllü by throwing into the sea. The birds on the wires represents the sad song of blond girl heard when Püsküllü lighted a fire on the seaside to meet with his blond love.

\subsubsection{Visualisation of woman in "Tuz Gölüne Dair Efsane/Legend of Salt Lake"}

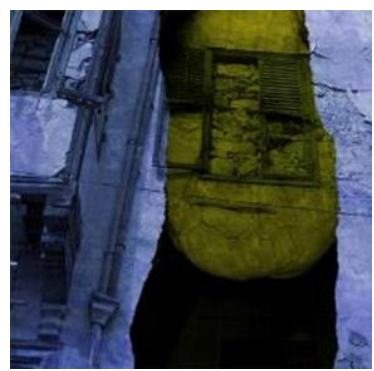

Figure 6. 'Woman' in the "Tuz Gölüne Dair Efsane/Legend of Salt Lake" Legend

In the Tuz Gölü/Salt Lake Legend, the 'old' woman described by 'grumpy' and 'stingy' features was represented by an old house with stonewalls. The old woman visual added on the stone covered visual expressed the 'cold' attitude of woman. The divine justice punished the woman, who caused the death of someone in need by not helping, with drying out the vineyard and turned her into stone. The stone texture on the background emphasized this feature.

\subsubsection{Visualisation of woman in "Yılan Adası/Snake Island" Legend}

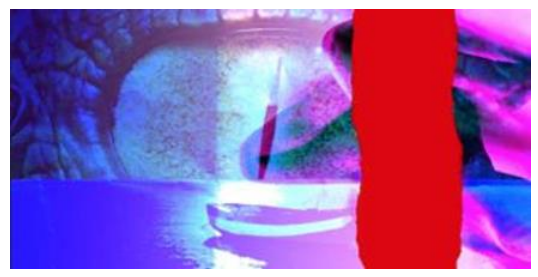

Figure 7. 'Woman' in the "Yılan Adası/Snake Island" Legend 
The 'angry nature' and 'power' of King with the power and authority were visualised by the eye of a sea snake and the blue colour was included for the concept of male hegemony. The empty boat was used to narrate the visit of King to the Snake Island where the fisherman, wife and daughter lived upon the disobedience of old fisherman and his daughter, and disappearance of the family after they sail away. The eye on the background visualised the King's observing and trying to find the family. The purple colour was chosen in the illustration of the upside down woman symbolising her without any family peace. As the woman was preferred due to her physical appearance and admired by the King because of her 'beauty' led to be interpreted as a 'sexual object' and therefore the torn texture visualised by the red colour.

\subsubsection{Assessment and women in the legend of "Sarnıç Kızlarının Ölümü/Death of Cistern Girls"}

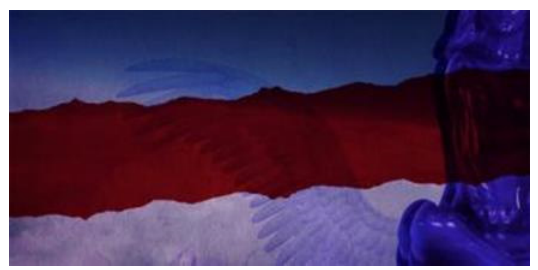

Figure 8. 'Woman' in the "Sarnıç Kızlarının Ölümü/Death of Cistern Girls" Legend

The women described in the legend called Sarnıç Kızlarının Ölümü/Death of Cistern Girls is narrated through the sacrifice of Shepherd Vakua's wife described as 'sinful' to the God and Angels at the cistern located in the Belen Plain. 'The sacrifice' is narrated with the red torn texture symbolising the blood while the figure of cross-legged woman is a portrait 'ready' to be sacrificed. The wing behind the woman is visualised as a part of an angel. The background with the sky visual represents that the woman was taken into the appearance of God by the angels.

\section{Conclusion and Recommendations}

\subsection{Conclusion}

Culture that covers information, belief, art, law, customs and traditions as a whole appears in two ways as indicated before. In accordance with the scope of study, for the first time the visualisation activities was conducted with the digital collage method to contribute the integration of intangible culture with the tangible culture.

In accordance with the main aim of this study, this study aimed to make the legends as a cultural product in the context of passing down from generations, making easier to remember, sharing more easily and -most importantlydeveloping the culture, which has the features of learning, sharing, developing through 'the visualisation'.

Considering the aforementioned statements, the legends refer to the communal telling in a brief and prose style making people to believe as well as considered as a product of ethnology in the literature. As known, the island of Cyprus is very prosperous in terms of legends due to its historical background and cultural motifs of various civilisations lived on the island.

Pursuant to the women and their situation under the Turkish Cypriot Legends within the scope of study, the created visuals included some homogenous indicators. Therefore, the woman in general was described as 'victim', 'meta' and rarely as 'sinful', in brief they were marginalised within the patriarchal legend structure.

Considering all of these aspects, regardless the positive or negative outcome for the woman, 'torn' (paper) background was used to represent and the emotions were symbolised with various colours. Preferably purple colour was used in the unfair or passivized circumstances for woman; and in parallel the hegemonic attitude of man in the legend was represented with blue colour (dark or light). The fury of God was symbolised with natural events and in order to remember that all events are a part of legends, the human bodies were used as naked. The sculptured bodies at times supported such fact.

\subsection{Recommendations}

In addition to the existing study, for the following studies, the visualisation of critical aspects such as point of conflict, man, main theme or fate rather than solely woman given in the legends would allow the enrichment of existing legends 
from the perspective of art.

Moreover, not only the legends under this study but also the visualisation of legends given in the sub-headings or woman discourses in all the Turkish Cypriot legends would allow to create an understanding about woman under the Turkish Cypriot legends in general, hence in the history.

Prior to making a generalisation in relation to the legends showing a patriarchal nature as a result of this study, the analysis to be performed on all legends would be beneficial. Additionally, a study covering the discursive representation of man, climaxes of events and their fates would create a knowledge on the early Turkish Cypriot culture in general.

\section{Declaration}

We confirm that the visuals do not breach any copyrights. In addition to this, we declare that the first author has copyright of the reproduced visuals.

\section{References}

Abbandonato, L. (1991). " A View from'Elsewhere'": Subversive Sexuality and the Rewriting of the Heroine's Story in The Color Purple. Publications of the Modern Language Association of America, 1106-1115.

Akdoğan, B. (2001). Sanat, sanatçı, sanat eseri ve ahlak. Ankara Üniversitesi Iletişim Fakültesi Dergisi, 42, 213-247.

Alptekin, A. B. (2013). Kuzey Kibris Türk Cumhuriyeti'nde Anlatilan Efsanelerin Motif Ve Tip Yapisi. Journal Of Türklük Bilimi Arastirmalari, 18(33).

Berger, J. (2004). Picasso'nun başarısı ve başarııızığı. DABAA.

Ergün, C. (2012). Temel sanat eğitiminde ve çağdaş sanatta kolaj-fotomontaj. Sanat-Tasarım Dergisi, 1(3), 5-19.

Gökçeoğlu, M. (2004). Kıbrıs Türk Halkbilimi Sözel Kültür Değerlerimiz: Efsanelerimiz. Lefkoşa: Gökçeoğlu Yayınları.

Greh, D. (1990). Computers in the Artroom. A Handbook for Teachers.

Lynton, N. (2009). Modern Sanatın Öyküsü, çev. Cevat Çapan-Sadi Öziş, Remzi Kitabevi, İstanbul.

Nesim, A. ve Oznur, S. (2011). Kıbrıs Türk Kültürü ve Kıbrıs Efsaneleri. Lefkosa: Gokada Yayinlari

Ozzkalp, E. (2005). Davranış, bilimlerine giriș. Eskișehir: Anadolu Universitesi Açıkö̆retim Fakultesi.

Rona, Z., \& Beykan, M. (1997). Eczacıbaşı Sanat Ansiklopedisi. YEM Yayınları, İstanbul.

Sağlamtimur, Z. Ö. (2010). Dijital Sanat. Eskişehir: Anadolu Üniversitesi Sosyal Bilimler Dergisi.

Şengül, E. (2006) Teknolojinin Görsel Sanatlarda Kullanımı ve Sanat Eğitimine Katkısı. Doktora Tezi, Hacettepe Üniversitesi, Ankara.

Serdar, G. (1966). 1571'den 1964'e Kıbrıs Türk Edebiyatında Gazavatnâme, Destan, Efsane, Kahramanlık Şiiri /Araştırma Inceleme, Mağusa.

Ünver, E. (2012). Sanat ve Toplum. Bilim-Teknoloki Dergisi

Wölfflin, H., \& Ors, H. (1985). Sanat tarihinin temel kavramları. Istanbul: Remzi Kitabevi. 